\title{
HYDROCARBON AND PETROLEUM WITH SETS APPROACH MODULE TO TRAIN STUDENTS' CRITICAL THINKING SKILLS
}

\author{
Dinda Karunia Putri ${ }^{1}$, Rusmini ${ }^{2 *}$ \\ ${ }^{1,2}$ Department of Chemistry Education, Faculty of Mathematics and Natural Sciences, Universitas Negeri \\ Surabaya, Indonesia
}

*Corresponding author: rusmini@unesa.ac.id

\begin{tabular}{|c|c|}
\hline Article Info & ABSTRACT \\
\hline Article history: & \multirow{6}{*}{$\begin{array}{l}\text { The aim of this study was to develop a module with the Science } \\
\text { Environment, Technology and Society (SETS) approach to train } \\
\text { critical thinking skills on hydrocarbons and petroleum using the } \\
\text { Research and Development (R\&D) method. This developmen } \\
\text { modul was validated by } 3 \text { experts, while the limited trial was only } \\
\text { limited to a small trial with } 3 \text { respondents from class XII students } \\
\text { of SMAN } 10 \text { Surabaya to obtain practical and effective data of } \\
\text { modules that developed on a small scale. This experiment obtained } \\
\text { expert validation results } 87 \% \text { with the "very valid" category } \\
\text { module practicality } 94 \% \text { with the "very practical" category and } \\
\text { module effectiveness of } 0.8 \text { with the "high" category. The } \\
\text { effectiveness of the module is obtained from the pretest and posttes } \\
\text { that } 3 \text { students have increased their critical thinking skills after the } \\
\text { module is given. Based on this study, it can be concluded that the } \\
\text { module with the SETS approach in the material of hydrocarbons } \\
\text { and petroleum can train students' critical thinking skills and it is } \\
\text { feasible to be tested on larger respondents. }\end{array}$} \\
\hline $\begin{array}{l}\text { Received: December 28, } \\
2021\end{array}$ & \\
\hline Accepted: January 29, 2021 & \\
\hline Published: March 13, 2021 & \\
\hline Keywords: & \\
\hline $\begin{array}{l}\text { Critical thinking } \\
\text { Module } \\
\text { SETS }\end{array}$ & \\
\hline
\end{tabular}

\section{MODUL MATERI HIDROKARBON DAN MINYAK BUMI BERPENDEKATAN SETS UNTUK MELATIH KETERAMPILAN BERPIKIR KRITIS SISWA}

\begin{tabular}{|c|c|}
\hline & ABSTRAK \\
\hline $\begin{array}{l}\text { Kata Kunci: } \\
\text { Berpikir kritis } \\
\text { Modul } \\
\text { SETS }\end{array}$ & $\begin{array}{l}\text { Penelitian ini bertujuan untuk mengembangkan modul } \\
\text { berpendekatan Science, Environment, Technology and Society } \\
\text { (SETS) guna melatihkan keterampilan berpikir kritis pada materi } \\
\text { hidrokarbon dan minyak bumi menggunakan metode Research and } \\
\text { Development (R\&D). Modul pengembangan ini divalidasi oleh } 3 \\
\text { ahli, sedangkan uji coba terbatas baru sampai small trial dengan } \\
\text { responden } 3 \text { siswa SMAN } 10 \text { Surabaya kelas XII untuk } \\
\text { mendapatkan data kepraktisan dan keefektifan modul yang } \\
\text { dikembangkan dalam skala kecil. Penelitian ini mendapatkan hasil } \\
\text { validasi ahli sebesar 87\% dengan kategori "sangat valid", } \\
\text { kepraktisan modul sebesar } 94 \% \text { dengan kategori "sangat praktis" } \\
\text { dan keefektifan modul sebesar 0,8 dengan kategori "tinggi". } \\
\text { Keefektifan modul didapat dari pretest dan postest bahwa } 3 \text { siswa } \\
\text { memiliki peningkatan keterampilan berpikir kritis setelah modul } \\
\text { diberikan. Penelitian ini dapat disimpulkan bahwa modul } \\
\text { berpendekatan SETS materi hidrokarbon dan minyak bumi dapat } \\
\text { melatihkan keterampilan berpikir kritis dan layak diujicobakan } \\
\text { kepada responden dengan skala yang lebih besar. }\end{array}$ \\
\hline
\end{tabular}




\section{INTRODUCTION}

Due to the high competition of the job needs in Indonesia, one of the way how to face the globalization is the development of Human Resources (HR) by cultivating and developing students' critical thinking skill. Critical thinking skill is one of the most important skills in real life. Students are expected to have critical thinking and communication skills for the future, as mentioned in the Next Generation Science Standard (NGGS)[1]-[3].

Critical thinking skills are components of higher-order thinking skills in reflective and logical thinking, reflecting on making appropriate decisions and actions [4],[5]. Decision making can be in the form of students' abilities to define problems, collect data/information obtained, analyze, and synthesize. Whereas determining action can be reflected in the form of the students' ability to find the solutions of the problems and decide what to do with the problems. Therefore, students are expected to have the ability to think critically so that they can become agents of change to $21^{\text {st }}$-century challenges [6],[7].

Students need practice, encouragement, guidance to get used to analyzing problems [8],[9]. Therefore, students need to access real learning experiences and problem-solving skills. Problem-solving experiences are given to students to act as a stimulus to trigger their critical thinking skills. Critical thinking skills will enable students to make appropriate decisions or actions on their problems [10],[11]. By using SETS vision learning, the students are expected to recognize the impact of technology on their social lives and know the real interactions between science for technology, society, and the environment [12],[13]. Learning with the SETS vision is is learning to understand science better and precisely, encourage students to think critically, and foster their creativity. SETS learning can also make abstract topics in the teaching science that usually boring becomes interesting and fun because they are linked to real life, so students can be motivated to learn. Student learning outcomes of chemistry are increasing [14],[15]. The relationship between the SETS components can be seen in Figure 1.

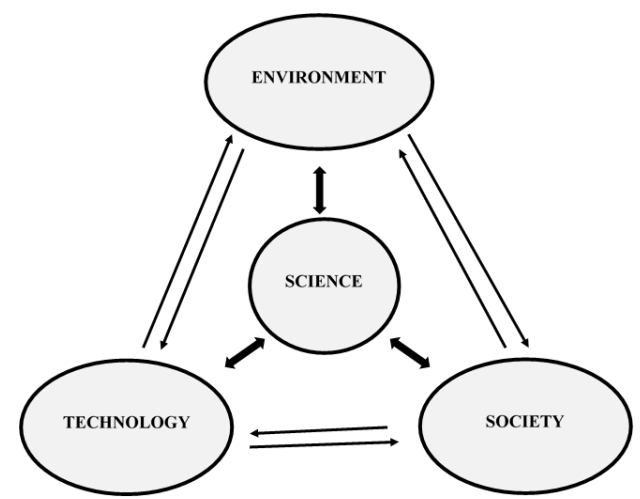

Figure 1. SETS Framework [16]

Learning chemistry, especially in hydrocarbons and petroleum, requires critical thinking skills. Hydrocarbons and petroleum studies cover topics and concepts related to science, environment, technology, and society's matters. Therefore, a suitable approach for studying hydrocarbons and petroleum is the Science, Environment, Technology, and Society (SETS) approach. The SETS learning approach is an approach that connects the relationship between science, technology, environment, and society [17],[18]. In the context of education with the SETS vision, the summary sequence of SETS carries the message that to use science in the form of technology to fulfill society's needs. It is necessary to think about its impact on the environment [19],[20]. 
Learning chemistry using the SETS approach can presents issues in life [21],[22]. It can indirectly practice the students' critical thinking processes because it can connect and integrate one concepts with other concepts. Integrating several topics or concepts with various related appropriate studies will make the learning and teaching process more interesting and meaningful. Students can easily understand a topic or concept from different perspectives and make sustainable relationships between concepts or topics with one another [23],[24].

Supported by the relevant research, it stated that in normal study still cannot encourage the students to practice their critical thinking for integrating the science in daily activities which has correlation with the environment, technology and society (ETS). Somehow, learning with SETS approach can improve students' critical thinking skills. It can be seen from the relevant research validation learning tools as $93.44 \%$ and $92.64 \%$ in the very valid category, the effectiveness measured with critical thinking skills as $87.5 \%$ and $88.3 \%$ and the practicality of the product with is known from positive students' responses as $92.6 \%$ and $88.60 \%$ [25]-[27].

All this time, learning chemistry has only relied on textbooks or worksheets as a learning resource. While textbooks have general contents so that the students need the teacher to explain the essence of the book and it makes one direction communication. Modules are arranged systematically which includes material content, methods and evaluations that can be used independently by students according to the expected competencies [28],[29]. The SETS approach module to improve critical thinking skills has never been used as a teaching material before and students do not get a variety of learning resources. The study about the ability of critical thinking is also existing and done by other researcher, but there is still no research that discuss about the use of SETS module to practice the students' critical thinking skill. The previous research are mostly developing the worksheet rather than the module. Based on school books / teaching materials observation that are still used in the usual approach, there are no books that use the SETS approach, especially on the hydrocarbons and petroleum chapters are found with no correlation with the environment, technology, and society (ETS). The common modules are developed without using SETS approach to practice students' critical thinking skills. So, with the development of a module with the SETS approach in the hydrocarbons and petroleum materials, it hopes that it can train students' critical thinking skills better.

\section{METHOD}

This study used the Research and Development (R\&D) method which aimed to develop module products with the SETS approach, which aims to practice critical thinking skills on hydrocarbon petroleum chapter. The development of the SETS approach module is feasible if it meets the validity aspects according to the expert (two lecturers and one teacher), practicality, and effectiveness when used by students. The instruments used were the validation sheet to determine the validity of the module, the student response sheet to determine the practicality of the module when it was used by students and the pretestpostest sheet to determine the increase in students' critical thinking skills which showed the effectiveness of the developed module. To find out the effectiveness of a media, there are 3 stages, namely one to one evaluation in which the number of respondents is 1-3 students, small group evaluation respondents are 10-15 students and the number of field evaluations involves a wider range of respondents. In this study using the test one-onone/small trial to three students of SMAN 10 Surabaya to obtain the comments of students and how well the products developed before been tested on a small group or field 
evaluation [30],[31]. The SETS approach is developed using the Borg and Gall procedure [28]. The research method includes ten steps, as shown in Figure 2.
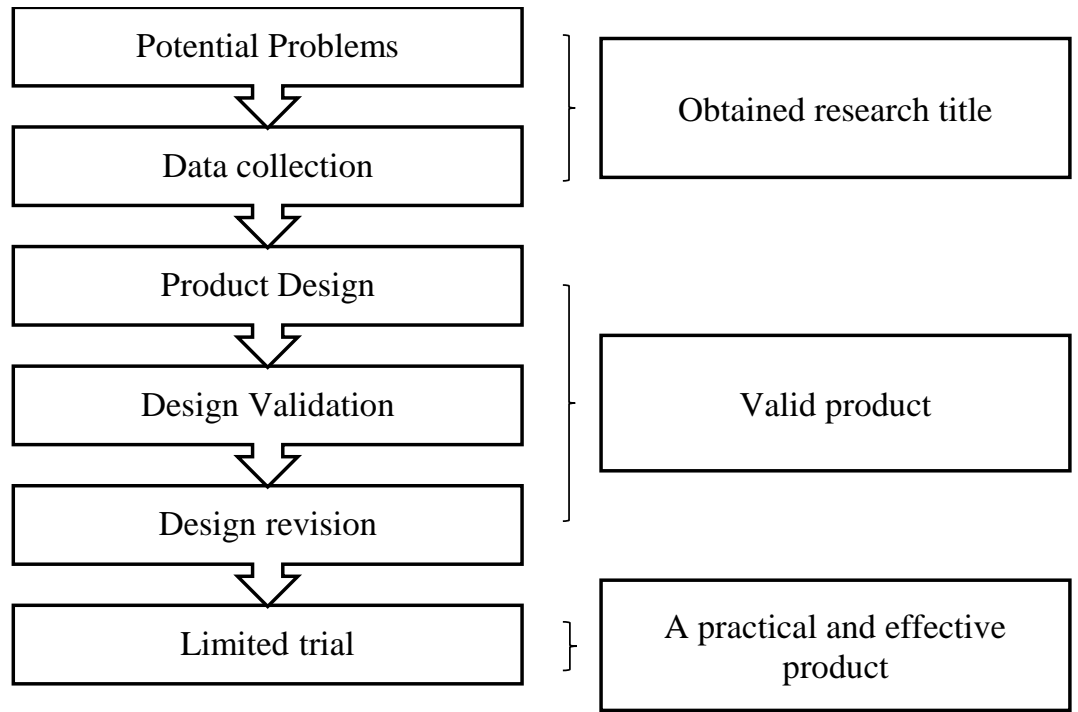

.Figure 2. The SETS Approach Module Development Procedure [32]

However, this study only reached the limited trial stage with a small trial of 3 students of SMAN 10 Surabaya, due to limitations in conducting trials due to the Covid19 pandemic. Analysis of validation data is calculated using a percentage of validity questionnaire data by three experts based on a Likert scale score and analysis of student response data using the Guttman scale.

However, this research is limited to the sixth stage, namely product testing for high school students who have received hydrocarbon and petroleum materials. Product trials using experimental designs (One-Group Pretest-Postets) as shown in Figure 3 below:

\section{$\mathrm{O}_{1} \times \mathrm{O}_{2}$}

Figure 3. Experimental Design (One-Group Pretest-Posttest)

$\mathrm{O}_{1}=$ Pretest before being given a SETS approach module

$\mathrm{X}=$ given treatment with a SETS approach module

$\mathrm{O}_{2}=$ Postest after being given a SETS approach module

The test data analysis was calculated using an n-gain score to determine the differences in critical thinking skills before (pretest) and after (posttest).

*

\section{RESULTS AND DISCUSSION}

In developing this product, there is a potential problem where students in the learning process are more directed to memorizing information. Students' minds tend to remember and accumulate information without understanding and relating to the real life, that is the basis for module research using the SETS approach. Furthermore, collect the data before the research has aimed to analyze and collect material from various sources to develop product planning. Literature studies at the potential problem and data collection state that students need to have critical thinking skills and the SETS approach can practice their critical thinking skills. In line with previous research, the aim of learning with the SETS vision is to enable students to understand science better, encourage students to be creative 
and think critically so that students can increase their motivation and their result of the study [14][15]. Those are the purpose of developing a module with the SETS approach to practice students' critical thinking skills on hydrocarbon and petroleum chapters.

The initial product development stage includes preparing draft I, validation, and revision to produce draft II. The development of draft I will be validated by three expert validators, namely 2 Chemistry Education lecturers at the State University of Surabaya and one chemistry teacher at SMAN 15 Surabaya, storyboard module can be seen in Table 1.

Table 1. Storyboard Module

\begin{tabular}{|c|c|c|}
\hline No & Visual & Explanation \\
\hline 1 & 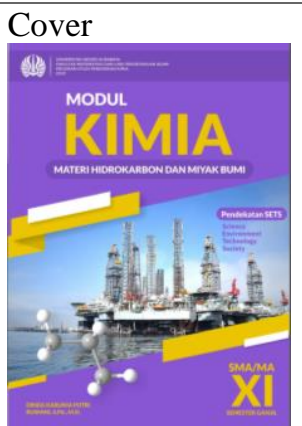 & $\begin{array}{l}\text { In the cover, there is a statement that the hydrocarbon and petroleum } \\
\text { modules use SETS approach }\end{array}$ \\
\hline 2 & $\begin{array}{l}\text { Concept Map } \\
\text { rexánser }\end{array}$ & $\begin{array}{l}\text { The concept map contains all sub-chapters in hydrocarbons and } \\
\text { petroleum. Hydrocarbons are grouped into aliphatic and aromatic } \\
\text { hydrocarbons. Hydrocarbons are contained in petroleum and can be } \\
\text { separated using multilevel distillation to produce petroleum products. } \\
\text { However, the process and use of petroleum causes environmental } \\
\text { pollution. }\end{array}$ \\
\hline 3 & 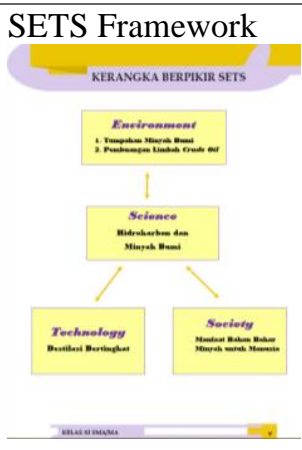 & $\begin{array}{l}\text { The SETS framework categorizes: } \\
\text { 1. Hydrocarbons and petroleum in the scientific aspect } \\
\text { 2. Petroleum spills and disposal of crude oil waste in environmental } \\
\text { aspects } \\
\text { 3. Separation of petroleum using multilevel distillation in the } \\
\text { technological aspect } \\
\text { 4. Benefits of petroleum for daily life in terms of society }\end{array}$ \\
\hline 4 & 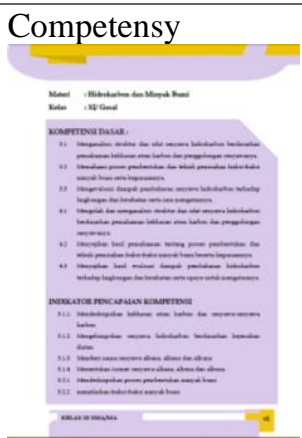 & $\begin{array}{l}\text { There are Basic Competencies (KD) starting from } 3.1 \text { analyzing the } \\
\text { structure and character of hydrocarbon compounds based on an } \\
\text { understanding of the peculiarities of carbon atoms and their } \\
\text { classifications of compounds up to } 4.3 \text { Presenting the results of } \\
\text { evaluation of the impact of hydrocarbon combustion on the } \\
\text { environment and health, and also how to overcome them }\end{array}$ \\
\hline
\end{tabular}




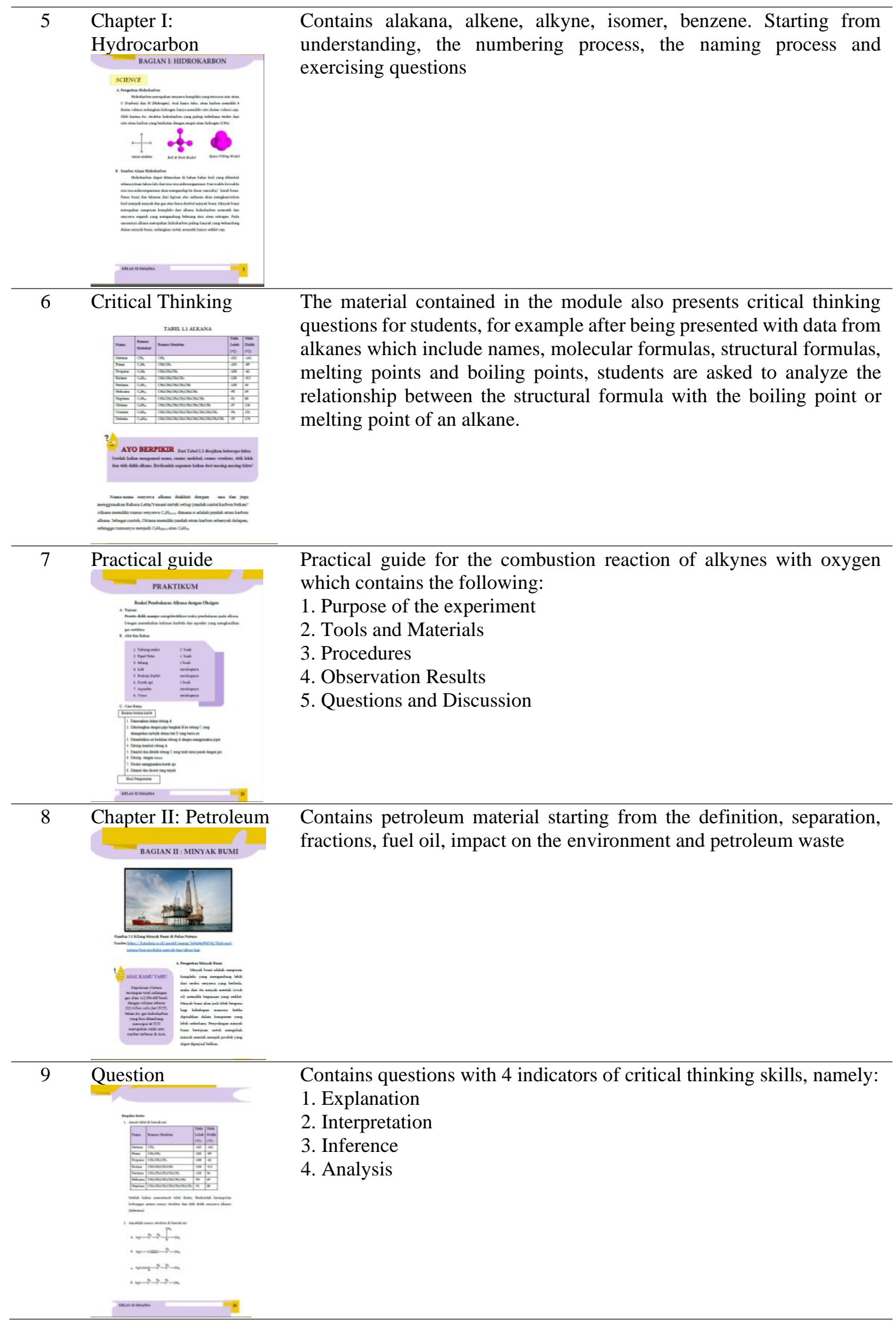


The module validation results consist of 3 aspects being assessed: content, language, and presentation. The following is the recapitulation result of the SETS approach module validation processed using the $n$-gain score in Table 2.

Table 2. Recapitulation of SETS Approach Module Validation

\begin{tabular}{clc}
\hline No & Component & Percentage \\
\hline 1 & Content & $87 \%$ \\
2 & Presentation & $90 \%$ \\
3 & Language & $84 \%$ \\
\hline Average & $87 \%$ \\
\hline Category & Very Valid \\
\hline
\end{tabular}

Content feasibility gets score of $87 \%$ with a very valid category, means that the module chapters are in accordance with Competency Standards (SK) and Basic Competencies (KD). The module chapters contain related aspects of SETS so that the SETS approach allows students to gain a complete understanding of science from their learning. The SETS approach is learning with an integrated process to teach students to look at the problems by paying attention to science, environment, technology, and society [33][34]. The module is equipped with a SETS chart to make the students easier to connect hydrocarbons and petroleum chapters into manufacturing technology, impact the environment, and impact society. There is also a competency test in the module that contains four critical thinking skills indicators: 1) Interpretation, 2) Analysis, 3) inference, and 4) explanation.

Presentation feasibility gets a value of $90 \%$ with a valid category, means that the module presentation technique is good. The material presented is systematic, starting from the introduction, table of contents, concept map, contents, conclusions, competency tests, and bibliography. The module is presented with pictures to assist students in understanding the chapter, namely when composing the module, illustrations/pictures/visuals are needed to get a real picture of the substance being studied [35]. Those pictures also mean to make students not to get bored when reading the module.

The feasibility of language gets a value as $84 \%$ with a very valid category, means that the language used is in accordance with the students' level of intelligence, in other words, students can easily understand materials. The module uses communicative and coherent language so that it is easy to understand. The use of words should be common words and widely used in the school environment / daily life [35]

Overall, the SETS approach module's assessment to practice critical thinking skills obtained a total average of $87 \%$ in the very valid category. From this score, it can be concluded that the developed module is feasible to test with the conditions for improvement in accordance with the validator's suggestions.

Trials are carried out to determine the practicality and effectiveness of the developed modules. The student's response can determine the practicality of a media after using the module. Students are given a questionnaire concerning the practicality of the content, language, and presentation. The student's assessment is $94 \%$ in the very practical category, means that the module developing was clear, easy to understand, and interesting. The module can increase students' knowledge about the hydrocarbon content in petroleum and its uses in daily life, and its impact on the environment.

Meanwhile, effectiveness is measure by completeness and improvement of students' critical thinking skills. Because critical thinking is the key to science education to prepare young generation to understand the influence of science, technology, and its impacts [36][37][38]. The following is a graphic presentation of the pretest and post test critical 
thinking skills recap in Figure 4 , a graph of improving students' critical thinking skills for each indicator in Figure 5. Figure 6 contains the students 'pretest and posttest answers. Figure 7 explains the trial flow of the SETS approach module and visualization of students' questions and answers to questions in the module recap in Table 3.

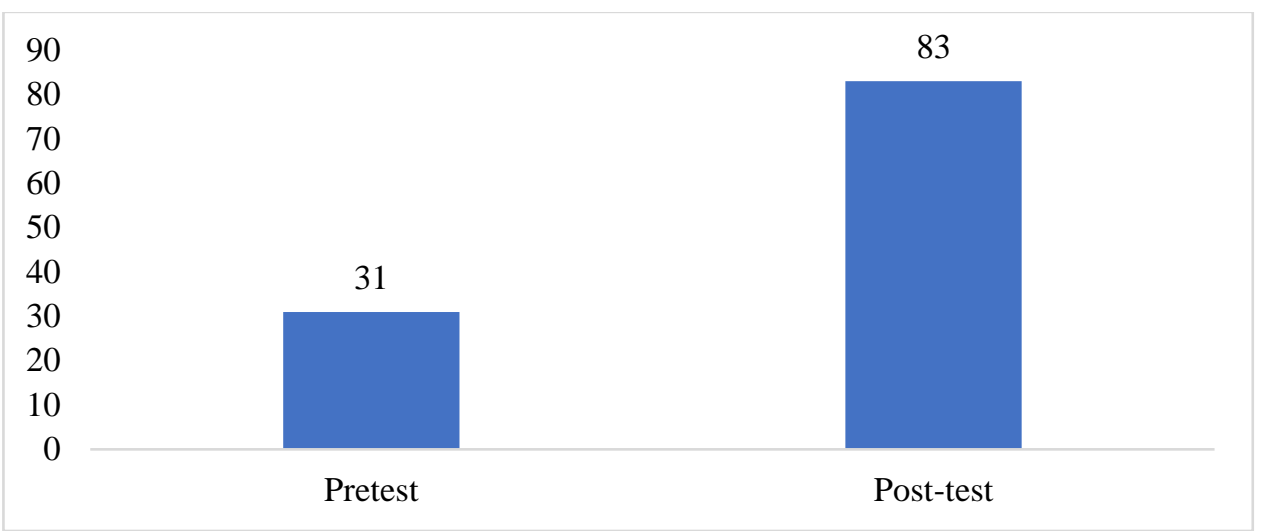

Figure 4. Graph of Pretest and Posttest Critical Thinking Skills Recapitulation

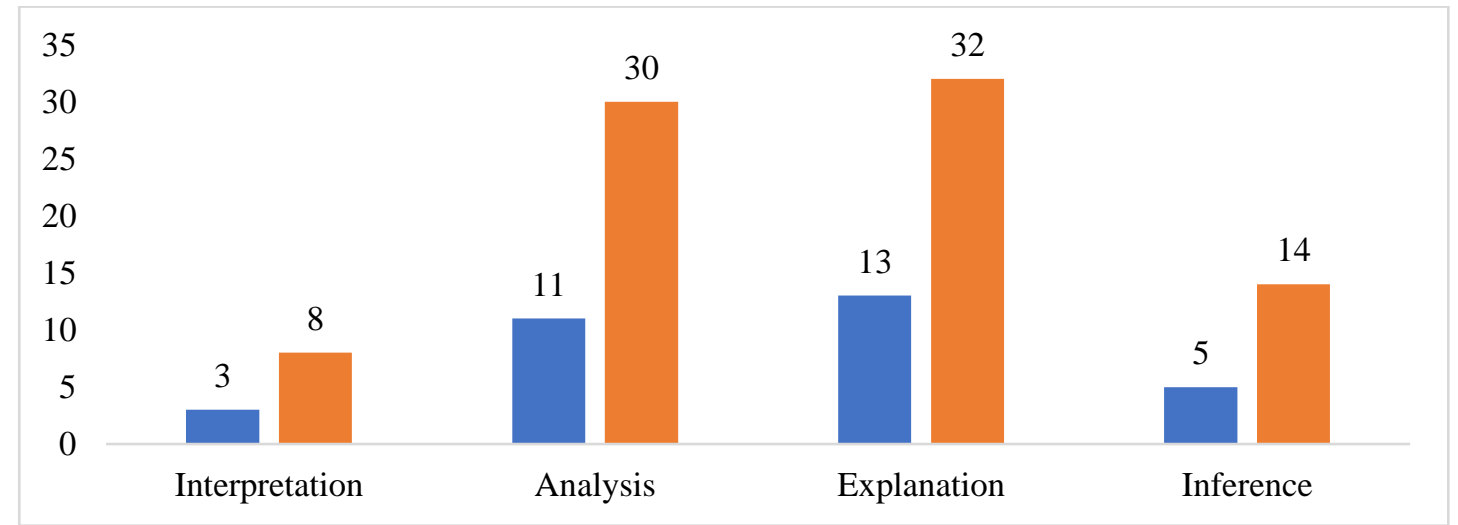

Figure 5. Graph of the Improvement of Students' Critical Thinking Skills for Each Indicator

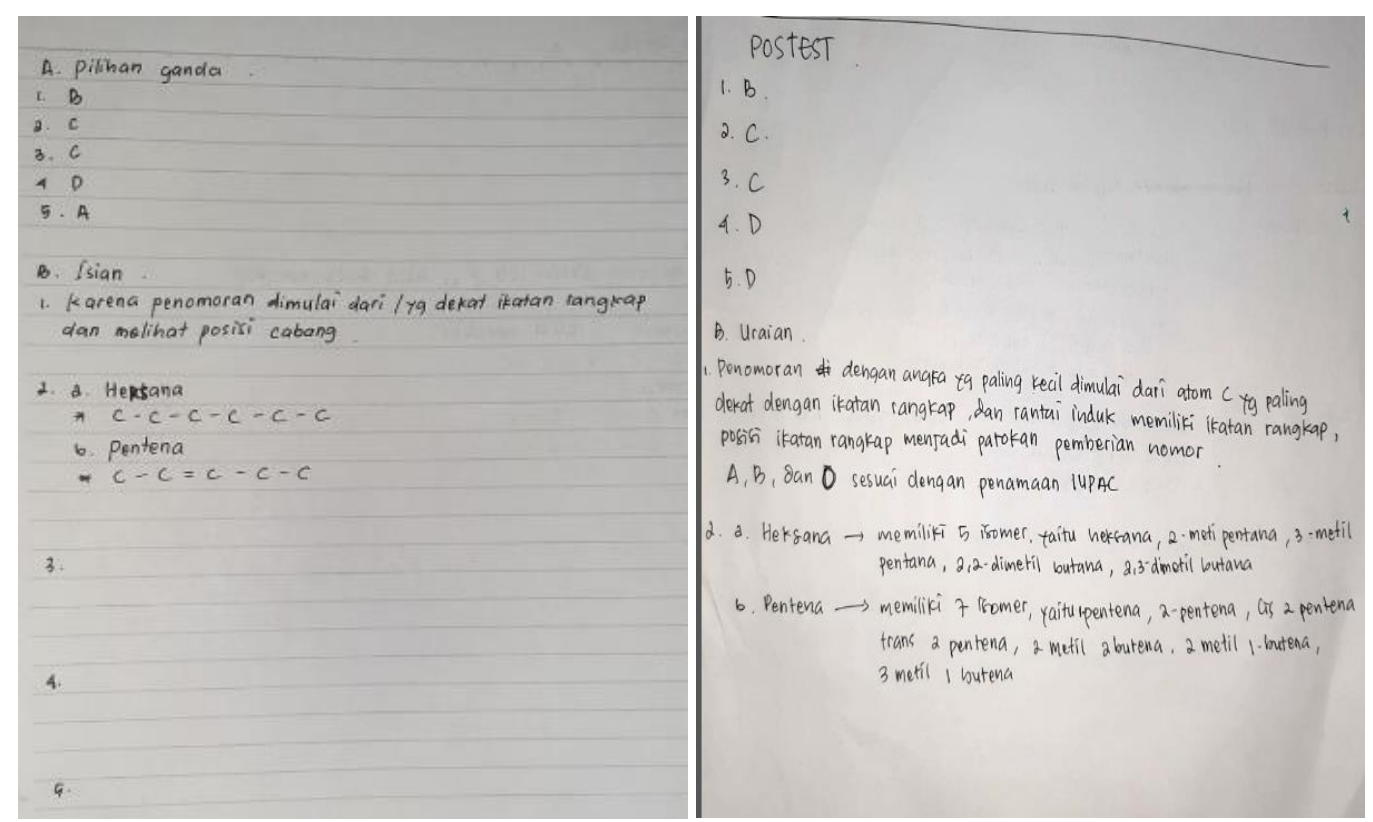

Figure 6. Students' Pretest and Postest Answers 


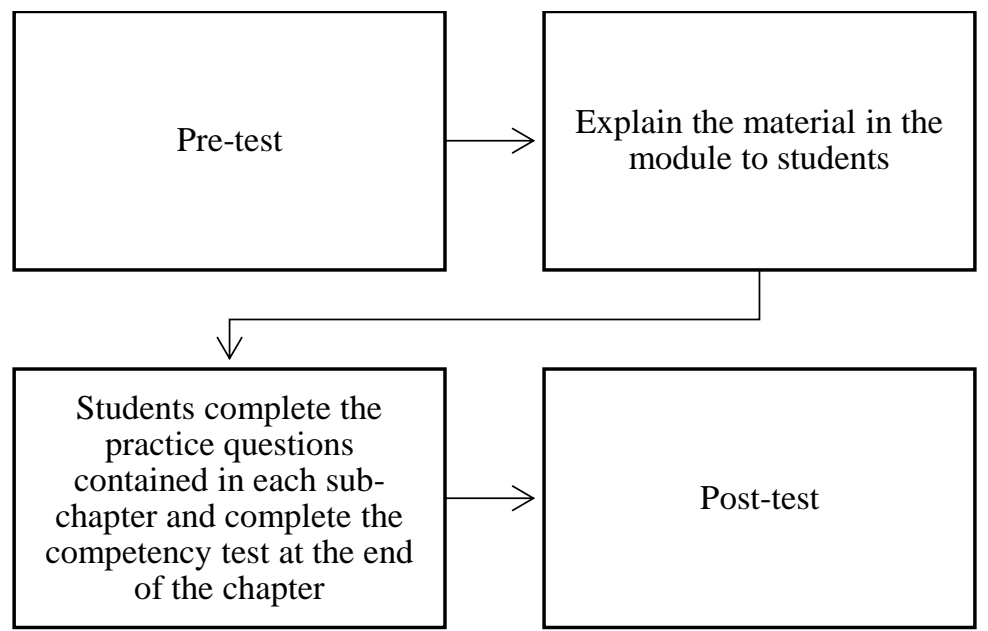

Figure 7. SETS Approach Module Trial Flow

Table 3. Visualization of Student Questions and Answers to Questions in the Module

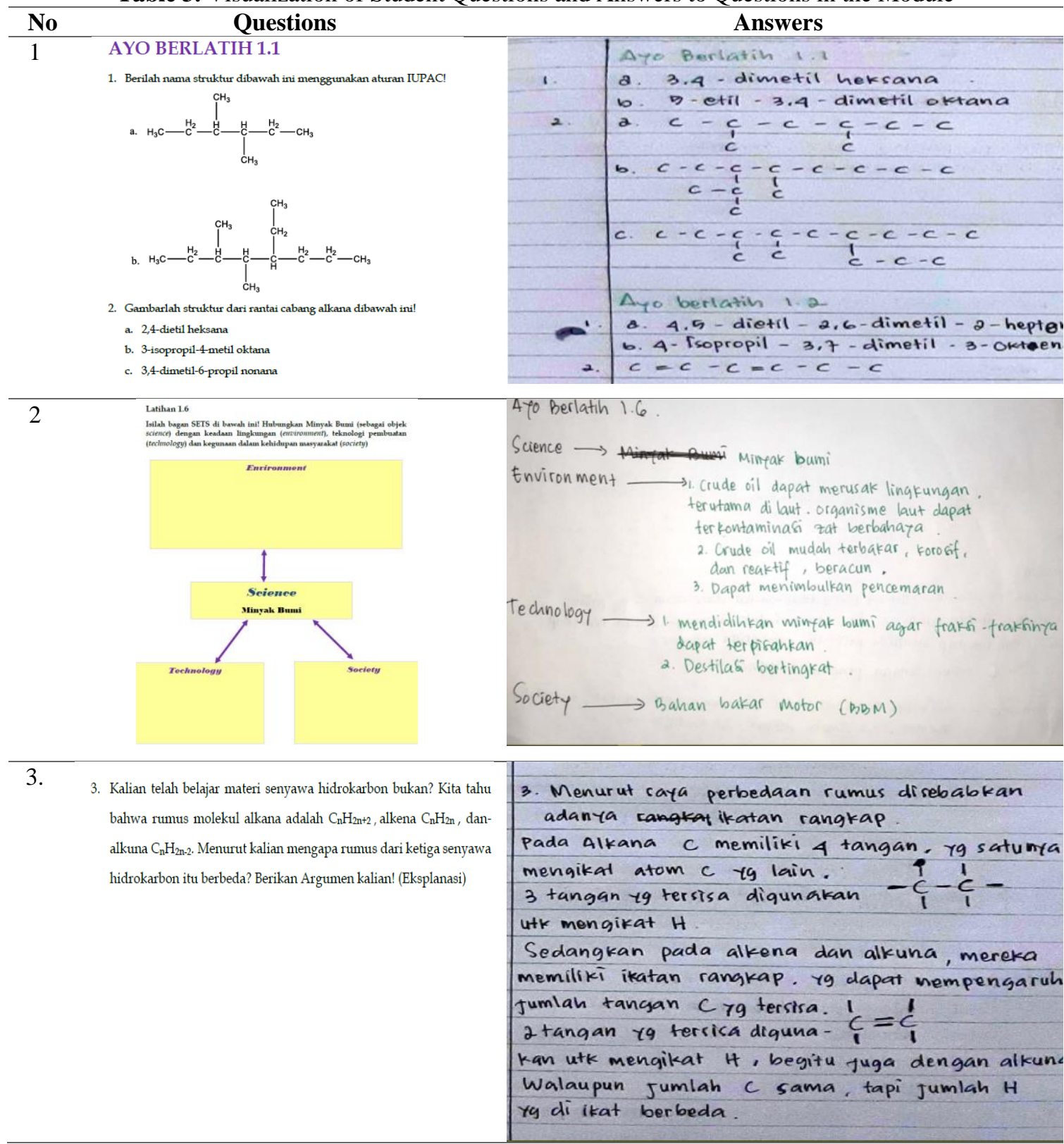


Based on Figure 4 and 5 shows that there is an increase in the completeness of critical thinking skills. The pretest results showed that none of the students had completed, but after being given treatment with the SETS approach module, student learning completeness as measured by the post-test increased. Whereas in Figure 4, the increase in each indicator of critical thinking skills during the pretest and post-test is very significant. It means that the module with the SETS approach can train students' critical thinking skills. $\mathrm{N}$-gain for each indicator of critical thinking skills can be seen in Table 4.

Table 4. N-Gain of Each Indicator of Students' Critical Thinking Skills

\begin{tabular}{lccc}
\hline Indicator & Pretest & Posttest & N-gain \\
\hline Interpretation & 3 & 8 & 1 \\
Analysis & 11 & 30 & 0,8 \\
Explanation & 13 & 32 & 0,8 \\
Inference & 5 & 14 & 0,7 \\
\hline Total & 32 & 84 & \\
\hline Average & & & 0,8 \\
\hline
\end{tabular}

Based on table 4 shows that the post-test results are much higher than the pretest. This condition happens because students receive treatment of SETS approach module as the teaching and learning material. The average n-gain value is 0.8 , which means that students' learning completeness was in the high category. The module with the SETS approach developed is very effective for practising students' critical thinking skills.

The SETS approach's learning module has the advantages that students can understand the chapters deeply, especially hydrocarbons and petroleum and have strong bonds in their lives. By presenting various events, problems, or issues in society, students are expected to develop thinking skills related to science, environment, technology, and society. It is in line with previous research using the SETS concept that is included in the learning process. Students can enhance and understand between branches of science, the technology used, benefits in society and impact on the environment so that students can show the improvement of their critical thinking skills [39]-[41].

The critical thinking skills that developed in the development of this module include the ability to provide opinions (interpretation), the ability to analyze, the ability to conclude (inference) and the ability to provide logical and relevant reasons for an event (explanation). By being given a module with the SETS approach, the students' ability in the 4 indicators increased by 0.8 when calculated by the n-gain score, it was known through the evaluation of the pretest-postest learning. So, it can be concluded that the hydrocarbon and petroleum module with the SETS approach can improve students' critical thinking skills. Whereas the module in the previous research that did not use the SETS approach to practice critical thinking skills on hydrocarbons and petroleum materials could only improve critical thinking skills during the pretest-postest of 0.71 [42].

\section{CONCLUSION}

This study was conducted to develop a product in the form of a hydrocarbon and petroleum module with the SETS approach to practice eleven graders of science students critical thinking skills. The method used for this research is $\mathrm{R} \& \mathrm{D}$, which gets the following results: The validity of the module, which includes content, language, and presentation, score $87 \%$ in the very valid category; the practicality of the developed modules as seen from the students' responses score as $94 \%$ in the very practical category and the effectiveness of the developed module is see through the completeness learning to get a score as 0.8 with the complete category and the average n-gain score with the high category 


\section{REFERENCES}

[1] L. Mutakinati, I. Anwari, and K. Yoshisuke, "Analysis of Students' Critical Thinking Skill of Middle School Through STEM Education Project-Based Learning," J. Pendidik. IPA Indones., vol. 7, no. 1, pp. 54-65, 2018, doi: 10.15294/jpii.v7i1.10495.

[2] N. R. Dewi, L. Magfiroh, S. Nurkhalisa, and I. Dwijayanti, "The Development of Contextual-Based Science Digital Storytelling Teaching Materials to Improve Students' Critical Thinking on Classification Theme," J. Turkish Sci. Educ., vol. 16, no. 3, pp. 364-378, 2019, doi: 10.12973/tused.10288a.

[3] S. Marni, "Students " Critical Thinking Skills Based on Gender And Knowledge Group," J. Turkish Sci. Educ., vol. 17, no. 4, pp. 544-560, 2020, doi: 10.36681/tused.2020.44.

[4] R. Mataniari, J. Willison, M. H. E. Hasibuan, U. Sulistiyo, and F. Dewi, "Portraying Students' Critical Thinking Skills through Research Skill Development (RSD) Framework: A Case of a Biology Course in an Indonesian University," J. Turkish Sci. Educ., vol. 17, no. 2, pp. 302-314, 2020, doi: 10.36681/tused.2020.28.

[5] F. Fakhriyah, "Penerapan Problem Based Learning dalam Upaya Mengembangkan Kemampuan Berpikir Kritis Mahasiswa," J. Pendidik. IPA Indones., vol. 3, no. 1, pp. 95-101, 2014, doi: 10.15294/jpii.v3i1.2906.

[6] A. Anisa, "Meningkatkan Keterampilan Berpikir Kritis Peserta Didik Melalui Pembelajaran IPA Berbasis Potensi Lokal Jepara," J. Inov. Pendidik. IPA, vol. 3, no. 1, p. 1, 2017, doi: 10.21831/jipi.v3i1.8607.

[7] S. Syarifah and Y. Sumardi, "Pengembangan Model Pembelajaran Malcolm'S Modeling Untuk Meningkatkan Keterampilan Berpikir Kritis Dan Motivasi Belajar Siswa," J. Inov. Pendidik. IPA, vol. 1, no. 2, p. 237, 2015, doi: 10.21831/jipi.v1i2.7510.

[8] I. W. Redhana, "Model Pembelajaran Berbasis Masalah dan Pertanyaan Socratik untuk Meningkatkan Keterampilan Berpikir Kritis Siswa," J. Cakrawala Pendidik., no. 3, pp. 351-365, 2013, doi: 10.21831/cp.v0i3.1136.

[9] A. Abdurrahman, C. A. Setyaningsih, and T. Jalmo, "Implementating Multiple Representation-based Worksheet to Develop Critical Thinking Skills," J. Turkish Sci. Educ., vol. 16, no. 1, pp. 138-155, 2019, doi: 10.12973/tused.10271a.

[10] M. Firdaus and I. Wilujeng, "Pengembangan LKPD Inkuiri Terbimbing untuk Meningkatkan Keterampilan Berpikir Kritis dan Hasil Belajar Peserta Didik," $J$. Inov. Pendidik. IPA, vol. 4, no. 1, pp. 26-40, 2018.

[11] A. Azar, "The effect of critical thinking dispositions on students achievement in selection and placement exam for university in Turkey," J. Turkish Sci. Educ., vol. 7, no. 1, pp. 61-73, 2010.

[12] M. A. Prayitno, N. K. Dewi, and N. Wijayati, "Pengembangan Modul Pembelajaran Kimia Bervisi Sets Berorientasi Chemo-Entrepreneurship (Cep) Pada Materi Larutan Asam Basa," J. Inov. Pendidik. Kim., vol. 10, no. 1, 2016.

[13] M. Imaduddin and F. F. Hidayah, "Redesigning Laboratories for Pre-service Chemistry Teachers: From Cookbook Experiments to Inquiry-Based Science, Environment, Technology, and Society Approach," J. Turkish Sci. Educ., vol. 16, no. 4, pp. 489-507, 2019, doi: 10.36681/tused.2020.3.

[14] N. Yörük, I. Morgil, and N. Seçken, "The Effects of Science, Technology, Ssociety, Environment (STSE) Interactions on Ceaching chemistry," Nat. Sci., vol. 02, no. 12, pp. 1417-1424, 2010, doi: 10.4236/ns.2010.212173.

[15] B. I. . Rosario, "Science, Technology, Society, and Environment (STSE) Approach 
in Environment Science for Nonscience Student in a Local Culture," Liceo J. High. Educ. Res. Sci. Technol. Sect., vol. 6, pp. 268-283, 2009.

[16] U. Maghfiroh and Sugianto, "Penerapan Pembelajaran Fisika Bervisi Sets Untuk Meningkatkan Kemampuan Berpikir Analitis Peserta Didik Kelas X," J. Pendidik. Fis. Indones., vol. 7, no. 1, pp. 6-12, 2011, doi: 10.15294/jpfi.v7i1.1061.

[17] Firdaus, "Pengembangan Media Pembelajaran Bervisi SETS Berbantuan Komputer untuk Meningkatkan Keterampilan Pemecahan Masalah,” Indones. J. Sci. Educ. Indones. J. Sci. Educ., vol. 1, no. 30286, pp. 17-29, 2017.

[18] A. C. Yusro, "Pengembangan Perangkat Pembelajaran Fisika Berbasis SETS Untuk Meningkatkan Kemampuan Berpikir Kreatif Siswa," J. Pendidik. Fis. dan Keilmuan, vol. 1, no. 2, p. 61, 2017, doi: 10.25273/jpfk.v1i2.13.

[19] A. Fatchan, H. Soekamto, and Y. Yuniarti, "Pengaruh Model Pembelajaran Science, Environment, Technology, Society (SETS) Terhadap Kemampuan Berkomunikasi Secara Tertulis Berupa Penulisan Karya Ilmiah Bidang Geografi Siswa SMA," J. Pendidik. dan Pembelajaran, vol. 21, no. 1, pp. 33-40, 2014.

[20] M. Zahra, W. Wati, and D. Makbuloh, "Pembelajaran SETS (Science, Environment, Technology, Society): Pengaruhnya pada Keterampilan Proses Sains," Indones. J. Sci. Math. Educ., vol. 2, no. 3, pp. 320-327, 2019, doi: 10.24042/ijsme.v2i3.4357.

[21] C. Damayanti, A. Rusilowati, and S. Linuwih2, "Pengembangan Model Pembelajaran Larutan Penyangga Berbasis Masalah Bervisi SETS,” J. Innov. Sci. Educ., vol. 6, no. 1, 2017.

[22] D. E. Avci, N. S. Onal, and M. Usak, "Turkish Teachers ' Opınıons about ScienceTechnology- Acquisitions in Science and Technology Course Curriculum," J. Balt. Sci. Educ., vol. 13, no. 2, pp. 216-231, 2014.

[23] A. Resni, S. Yamtinah, and S. B. Utomo, "Penggunaan Pendekatan SETS (Science, Environment, Technology and Society) pada Pembelajaran Asam, Basa, dan Garam untuk Meningkatkan Minat Belajar, Rasa Ingin Tahu, dan Prestasi Belajar Peserta Didik Kelas VII A Semester I SMP N 3 Karanganyar," J. Pendidik. Kim. Univ. Sebel. Maret, vol. 2, no. 3, pp. 108-113, 2013.

[24] D. Rosana, N. Kadarisman, and I. G. P. Suryadarma, "SSETS Best Practice Model: Growth Optimization and Productivity of Organic Food Plants through Iasmuspec Application," J. Pendidik. IPA Indones., vol. 8, no. 2, pp. 267-278, 2019, doi: 10.15294/jpii.v8i2.19248.

[25] U. Hasanah, "Validity of SALINGTEMAS Based-Worksheet on Fungi Topic to Influence Critical Thinking Skill," BioEdu, vol. 8, no. 3, pp. 20-25, 2019.

[26] Pramesthi and A. Dewi, "The Implementation of Student Worksheet Based on SALINGTEMAS Approach on Ecosystem Topic to Practice Critical Thinking Skills Students," BioEdu, vol. 2507, no. 1, pp. 1-9, 2020.

[27] S. \& R. Fitra Fadliani, "Development of Student Worksheet (SWs) Based on SETS (Science, Environment, Technology And Society) of Chemical Equilibrium," $J$. Online Mhs., vol. 7, pp. 1-12, 2020.

[28] A. Anggraini and S. Sukardi, "Pengembangan Modul Prakarya Dan Kewirausahaan Materi Pengolahan Berbasis Product Oriented Bagi Peserta Didik Smk," $J$. Pendidik. Vokasi, vol. 5, no. 3, p. 287, 2015, doi: 10.21831/jpv.v5i3.6484.

[29] L. Puspita, "Pengembangan Modul Berbasis Keterampilan Proses Sains sebagai Bahan Ajar dalam Pembelajaran Biologi," J. Inov. Pendidik. IPA, vol. 5, no. 1, pp. 79-88, 2019, doi: 10.21831/jipi.v5i1.22530.

[30] Ri. Agustini, "Pengembangan Multimedia Interaktif Teknik Jahit Perca Kelas X Desain Kriya Tekstil SMK Negeri 2 Sewon,” J. Pendidik. Kiriya, 2016. 
[31] S. A. Sadiman, Skala Pengukuran Variabel-Variabel Penelitian. Depok: Raja Grafindo Persada, 2005.

[32] I. K. Setiawati and Senam, "Pengembangan Perangkat Pembelajaran IPA Berbasis SETS untuk Meningkatkan Scientific Literacy dan Foundational Knowledge," J. Inov. Pendidik. IPA, vol. 1, no. 2, p. 178, 2015, doi: 10.21831/jipi.v1i2.7503.

[33] Esmiyanti, S. Haryani, and E. Purwantoyo, "Pengembangan Modul IPA Terpadu Bervisi SETS (Science, Environment, Technology, and Society) pada Tema Ekosistem," Pengemb. Modul ipa terpadu bervisi SETS (science, Environ. Technol. Soc. pada tema Ekosist., vol. 5, no. 3, pp. 1418-1423, 2016.

[34] P. Amita, T. Prasasti, and I. Listiani, "SETS-Based Guided Experiment Book: Empowering Science Process Skills of Elementary School Students," Indones. J. Biol. Educ., vol. 4, no. 3, pp. 257-262, 2018.

[35] H. Sofyan, Pedoman Pengembangan Bahan Ajar, A Sudijono. Yogyakarta: IKIP Yogyakarta: Raja Grafindo Persada, 2008.

[36] A. Cahyarini and S. Rahayu, "The Effect Of 5e Learning Cycle Instructional Model Using Socioscientific Issues ( SSI ) Learning Context on Students ' Critical Thinking," J. Pendidik. IPA Indones., vol. 5, no. 2, pp. 222-229, 2016, doi: 10.15294/jpii.v5i2.7683.

[37] H. Suwono, H. E. Pratiwi, H. Susanto, and H. Susilo, "Enhancement of Students ' Biological Literacy and Critical Thinking of Biology Through Socio-Biological," J. Pendidik. IPA Indones., vol. 6, no. 2, 2017, doi: 10.15294/jpii.v6i2.9622.

[38] R. M. Vieira and C. Tenreiro-vieira, "Fostering Scientific Literacy and Critical Thinking in Elementary Science Education," Int. J. Sci. Math. Educ., pp. 659-680, 2016, doi: 10.1007/s10763-014-9605-2.

[39] M. Frank and A. Barzilai, "Project-Based Technology: Instructional Strategy for Developing Technological Literacy," J. Technol. Educ., vol. 18, no. 1, pp. 39-53, 2006, doi: 10.21061/jte.v18i1.a.3.

[40] F. P. Setiyono, "Pengembangan Perangkat Pembelajaran Kimia Kelarutan dan Hasil Kali Kelarutan (Ksp) dengan Pendekatan SETS untuk Meningkatkan Kreativitas dan Hasil Belajar Peserta Didik," J. Educ. Res. Eval., vol. 1, no. 1, pp. 149-158, 2012.

[41] A. Sugiarto and D. Djukri, "Pembelajaran Berbasis SETS Sebagai Upaya Meningkatkan Kreativitas dalam Pemecahan Masalah Pencemaran Lingkungan," $J$. Inov. Pendidik. IPA, vol. 1, no. 1, p. 1, 2015, doi: 10.21831/jipi.v1i1.4527.

[42] A. Rahmi, Y. Yusrizal, and I. Maulana, "Pengembangan Bahan Ajar Modul Pada Materi Hidrokarbon Di SMA Negeri 11 Banda Aceh," J. Pendidik. Sains Indones., vol. 2, no. 1, pp. 12-26, 2014. 